\title{
Energy Consumption in the Ecuadorian Economy, Empirical Analysis Trough the Method of Vector Autoregressive (VAR),
} 1973-2006

\author{
Juan Manuel García-Samaniego \\ Universidad Técnica Particular de Loja (UTPL), Loja, Ecuador \\ Universidad Nacional Autónoma de México (UNAM), Ciudad de México, Distrito Federal, México \\ Luisa María Reyes Yaguana \\ Universidad Técnica Particular de Loja (UTPL), Loja, Ecuador
}

\begin{abstract}
Several authors have been able to establish the relationship between energy consumption and economic growth. Empirical evidence shows different effects depending on the size and economic structure of a country to energy ratio, Gross Domestic Product (GDP), and employment. Historically the case of Ecuador, the study of energy consumption and economic growth has not been discussed, despite its importance in the generation of development policies. So the idea of analyzing the effects of energy consumption in Ecuador's economic growth with reference to the period 1978-2009, and also to know which variables determine it. Through a program econometric equation was estimated vector autoregressive model, in order to meet the long-term based on the Johansen's methodology estimates a vector error correction to analyze and describe the effects on the short term. Presents tools of analysis of these models, impulse response and decomposition of the variables, which extends the study of the trajectory of the variables mentioned. The results of this study show that the relationship between energy consumption and economic growth, maintain a direct and positive energy prices. Employment front there is a negative impact. In conclusion to Ecuador, reminiscent of developed countries, energy consumption has a positive effect on economic growth thereof; industrialization generates increased energy while decreasing unskilled jobs, thus the creation of more spaces use of specialized type, at the same time increasing energy consumption, generates increased price of it, or its derivatives.
\end{abstract}

Keywords: power consumption, Ecuador, economic growth, employment, vector autoregressive

\section{Introduction}

Theories of development and energy consumption have been widely discussed through different econometric models (Galindo \& Sánchez, 2005; Mabey, Smith, Hall, \& Gupta, 1997; Jorgenson, 1998; Pindyk, 1979). The use of VAR models represents simple estimate and in many cases more reliable results than those of

Juan Manuel García-Samaniego, Ph.D., Principal Research of The Institute of Economic Research, Universidad Técnica Particular de Loja (UTPL); Ph.D., Universidad Nacional Autónoma de México (UNAM).

Luisa María Reyes Yaguana, Research Assistant, Institute of Economic Research, Universidad Técnica Particular de Loja (UTPL).

Correspondence concerning this article should addressed to Juan Manuel García-Samaniego, San Cayetano alto s/n, Building UPSI, floor 2. E-mail: mgarcia@utpl.edu.ec; samaniego@comunidad.unam.mx.s. 
simultaneous equations. The relationship among GDP, energy consumption and unemployment, can be analyzed for developed and underdeveloped economies. Indeed, in the former, the existence of information has enabled more comprehensive studies, although these do not have natural resource intensity factor not renewable.

Underdeveloped countries are resource-intensive, however, this reality has become plenty of curse (Acosta, 2009) that has become dependent on the extraction of natural resources (metals and fossils) for their export (economies weak as those in Latin America). Ecuador is going through a change in production system, including development of the production code and zoning law in Ecuador and the rescue of the state planning system and energy sovereignty. In this process, energy must play an important role because of its importance as an essential input to all productive activities and to meet basic needs of population (MEER, 2008).

Thus, there is a need to establish the relationship between energy consumption and economic growth through the Gross Domestic Product (GDP), and the impact and relative price effects of energy consumption and find the relationship among economic growth, GDP, and energy efficiency. To answer these questions we need to analyze and determine the variables that influence both energy consumption and economic growth. Likewise, the concern arises in through an econometric model, specifically to a Vector Autoregressive (VAR) which could explain the relationship between energy and GDP for the period 1973-2006.

This research outlines show the studies with respect to energy consumption and energy growth of Ecuador for the period 1973-2006, and the relationship of complementarily which are employment and energy. The second section presents the model results VAR by impulse response analysis and variance decomposition. Respective conclusions are made and finally presented in the Appendixes to the model tests.

The authors show that the relation between energy consumption and GDP is direct, positive relationship also in the GDP energy consumption with respect to the energy prices show a positive trend in consumption showing no sustainability or at least weak sustainability.

\section{Theoretical Framework}

Energy consumption is a primary factor for the functioning of any modern economy and represents an essential element to define the strategy for sustainable economic development. However, the energy consumption behavior and the relationships established with key macroeconomic variables have been studied in greater detail in the case of first-world nations. The absence of these studies for emerging economies and developing countries is a link that must be bridged between economics and theories of sustainable development (Galindo \& Sánchez, 2005).

Because of this, it is necessary to determine the appropriate transmission channels among economic growth, GDP, and energy efficiency (studied from the viewpoint of energy consumption). For Ecuador, currently being immersed in a process of restructuring, its energy matrix enables to identify and implement new forms of renewable energy. It should be recognized that the ways in establishing these relationships between energy and major macroeconomic variables have different impacts from the point of view of energy policy (MEER, 2008).

The Ecuadorian primary energy production in 1998 reached 988 petajoules (PJ) (1015 joules), increasing 925 PJ in comparison with 1970, mainly due to the activities of commodity exports. In 1970, as a percentage of primary energy production, renewable energy (wood, bagasse, and hydropower) reached $77 \%$, while the remaining $23 \%$ consisted of non-renewable energy (oil and natural gas). The primary renewable energy 
production dropped dramatically to $8 \%$ of the total in 1998. Ecuador's energy sector has been characterized by a high and steady growth in terms of supply and demand. In 2000, electricity generation was 10,607 GWh compared with $944 \mathrm{GWh}$ in 1970. This growth is a response to increased demand for electricity and the expansion of service coverage. Of the total energy production, $70 \%$ came from hydropower in 2000 . The installed capacity of power generation reached a total of 3,499 megawatts (MW) in 2000, coming in balance of power plants and 44\% from hydroelectric plants (Falconi Benitez, 1995).

The sectors of manufacturing, construction, and services had strong growth during the oil boom (1970). The commercial sector had strong growth during the 1980s (9.1\% annually), while construction declined by $4.2 \%$ with the exception of the latter, the use of energy in all sectors grew during the 1990s. Regarding the agricultural sector from 1970 to 1980, energy consumption grew at an average rate of 5.3\%. The annual energy consumption of the agricultural sector was $6.2 \%$ for the period from 1980 to 1990. The growth of energy consumption in the agricultural sector increased again during 1990 to 1998 at an average rate of 5.8\%.

The intensity of fuel use and energy conversion depends largely on the sectors of capital intensity versus the intensity of labor sectors. The reduction in fuel use is correlated with a higher level of technology and energy efficiency. Therefore, the ratio of energy/GDP (E/GDP) (usually called "energy intensity") is not free from criticism. Falconi Benitez (2002) indicated that in the case of industrialized countries, the effects of changes in power quality (and changes in energy prices, types of goods, services produced, and consumed) explain the reduction of the ratio E/real GDP. The decrease of this ratio in industrialized economies has been produced in part by the shift from coal to oil, gas, and primary electricity (hydro and nuclear), as well as by changes in the composition of the fuels used in final demand (gasoline or electricity used by households), in contrast to the demand of the downstream (oil and electricity used by industries), or vice versa.

In studies for the State of Mexico (Galindo \& Sánchez, 2005; Caballero Güendolian \& Galindo Paliza, 2006) examined the relationship between GDP and energy using a VAR model because of the convenience and best results from this technique. The analysis of the relationships established among power consumption, output, employment, and relative prices are widely discussed topics. For Galindo and Sánchez (2005), economic theory has several ways of looking at the aggregate level of the relationship among energy consumption, output, employment, and prices. There are microeconomic models (bottom up) and cut macro (top down). In the latter case there are two kinds of models: First, the computable general equilibrium (CGE) has an important consistency with economic theory and incorporates the behavior of optimizing agents.

The statistics is also applied through econometric models to analyze these relations (energy-GDP-employment), as the second model. It is possible to build econometric models with the computable general equilibrium models, which do not depart from the basic parameters of robustness and statistical confidence (Mabey, Smith, Hall, \& Gupta, 1997; Jorgenson, 1998). Using a VAR model is intended to give flexibility to the estimation process whereas the case of Ecuador, there is little information on the forms of adjustment of economic agents or the income and price elasticity.

Falconi Benitez (2002) said that hypothesis of the intensity of use, under which revenues presented as the main reason to justify explanatory material consumption. According to this hypothesis, during the process of economic development, countries increase their consumption of energy and materials in accordance with income growth to reach an income level defined, analogous to the behavior of the Environmental Kuznets Curve. Stern and Cleveland (2003) underlined the cointegration relation between energy and output, when 
included in the analysis of the relative prices of energy and other productive inputs.

Falconi Benitez (2002) performed a study that defines the relationship energy consumption growth as the ratio of energy/real GDP in Ecuador and concluded that energy consumption and GDP are positively correlated in statistical terms. GDP elasticity demand reached 0.69 between 1970 and 1998 . This elasticity indicates that energy consumption increases by $0.69 \%$ when real GDP changes by $1 \%$.

Studies by Mabey, Smith, Hall, and Gupta (1997), Howarth, Schipper, and Anderson (1993), also agreed that at a more applied level there is a tendency to consider energy consumption as an entity arising from trajectory of the product and its structural composition, technical progress, and changes in relative prices.

This is why it is necessary to accurately identify changes in energy intensity and productivity to assess possible pathways including the relative price of energy or the terms of complementarity of energy relative to other productive inputs such as employment.

In this study the authors model the energy consumption based on demand (energy) that depends on income (GDP) and relative prices. When an input power of the production function can evaluate its contribution to employment (Jorgenson,1984), from this it can be inferred that the reduction of energy supply can have negative consequences on the product, depending on the complementarity with employment. In this last premise, writers such as Chung (1994), stated that the work is a substitute, energy, and capital, while Pindyck (1979) considered complementary. And finally based on Mabey, Smith, Hall, and Gupta (1997), who argued that there is a stable relationship among energy intensity, relative prices, and a trend variable.

\section{Methodology}

Depending on the databases of the Central Bank of Ecuador (BCE) World Bank (WB) and the Economic Commission for Latin America and the Caribbean (ECLAC), the authors obtained a reliable time series for the period 1973-2006. Once collecting and validating this information and knowing economic theory, the authors use the econometric software (Eviews) to make estimates for a vector autoregressive model (VAR) that explains the consumption ratio energy and economic growth as much as possible.

The database used in this analysis includes annual data for the period 1973-2006. The following is the allocation of indicators and symbols of each of the variables used (see Table 1).

Table 1

Model Variables

\begin{tabular}{|l|l|l|}
\hline Symbology & Indicator & Source \\
\hline PIB & GDP at constant 2000 prices & Central Bank of Ecuador \\
\hline U & Unemployment rate & Central Bank of Ecuador \\
\hline PPET & Oil prices & Central Bank of Ecuador \\
\hline IPC & Consumer price index base year 2005 & World Bank \\
\hline PPET/IPC & Relative price of energy & Central Bank of Ecuador/World Bank \\
\hline CEPE & Energy consumption in thousands of barrels of oil & Economic Commission for Latin America and the Caribbean \\
\hline
\end{tabular}

The authors used the Augmented Dickey-Fuller test (ADF) to verify the integration order of each variable of the model, and observed that all variables have an order of I (1), Appendix A is the tests on each variable.

Upon verification of non-stationary of the variables area available to run the VAR model (Appendix A). The number of laps was selected based on the LAGSTRUCTURE test, specifically the lag screening test, it 
suggests a lag. With the help of an exogenous variable, in this case a trend variable as the "@trend", the authors obtained a correct model specification (Appendix B). Also, the model passes the tests of normality, autocorrelation, and hetero scedasticity, for support to this testing is presented in Appendixes D, E, and F respectively.

Here are the equations for the VAR model.

\section{Mathematical Model}

Equation 1.a

$$
C E P E=C(1,1) * C E P E(-1)+C(1,2) * G D P(-1)+C(1,3) * \frac{P P E T(-1)}{I P C(-1)}+C(1,4) * U(-1)+C(1,5)+C(1,6) * @ T R E N D
$$

Equation 2.a

$$
G D P=C(2,1) * C E P E(-1)+C(2,2) * G D P(-1)+C(2,3) * \frac{P P E T(-1)}{I P C(-1)}+C(2,4) * U(-1)+C(2,5)+C(2,6) * @ T R E N D
$$

Equation 3.a

$$
\frac{P P E T}{I P C}=C(3,1) * C E P E(-1)+C(3,2) * G D P(-1)+C(3,3) * \frac{P P E T(-1)}{I P C(-1)}+C(3,4) * U(-1)+C(3,5)+C(3,6) * @ T R E N D
$$

Equation 4.a

$$
U=C(4,1) * C E P E(-1)+C(4,2) * G D P(-1)+C(4,3) * \frac{\operatorname{PPET}(-1)}{\operatorname{IPC}(-1)}+C(4,4) * U(-1)+C(4,5)+C(4,6) * @ T R E N D
$$

\section{Econometric Model}

Equation 1.b

CEPE $=0.613 * C E P E(-1)+0.340 * \operatorname{GDP}(-1)+5.525 * \frac{\operatorname{PPET}(-1)}{\operatorname{IPC}(-1)}+7.873 * U(-1)+3072.914+362.207 * @ T R E N D+u_{i}$

Equation 2.b

$\boldsymbol{G P D}=-0.0125 * C E P E(-1)+0.786 * G D P(-1)+0.094 * \frac{P P E T(-1)}{\operatorname{IPC}(-1)}-74.935 * U(-1)+2086.173+111.51 * @ T R E N D+u_{i}$

Equation 3.b

$\frac{P P E T}{I P C}=-0.00739 * C E P E(-1)+0.0355 * G D P(-1)+0.626 * \frac{P P E T(-1)}{I P C(-1)}-2.724 * U(-1)+32.36-8.710 * @ T R E N D+u_{i}$

Equation 4.b

$$
U=0.0003 * C E P E(-1)-0.001 * \operatorname{GDP}(-1)+0.004 * \frac{\operatorname{PPET}(-1)}{\operatorname{IPC}(-1)}+0.191 * U(-1)+4.287+0.285 * @ T R E N D+u_{i}
$$

For the difficulty in interpreting the coefficients of the VAR model, the authors proceed to analyze the model forecast tools such as impulse response function and decomposition of the variable.

\section{Impulse Response}

Answer electricity consumption (CEPE) versus shock in GDP (GDP). Faced with an increase in GDP, measured by increased productivity, improved exports, energy consumption will tend to move positively in the short and long term. It makes sense that energy is an input which is positively related to GDP, as many sectors of economic activity and production of the country make use of it right.

According to Galindo and Sánchez (2005), an increase in income (GDP) results in a more than proportional growth in energy demand, which can only be partly offset by a price increase or employment.

Consumer Response Electrical (CEPE) versus the relative price shock (PPET/IPC). The oil prices are highly volatile, highly dependent on supply and demand of oil. Compared to an increase in the relative price of energy in this case measured by the ratio PEET/IPC, which will result in the medium term growth in energy consumption, but in the long run it will tend to an inverse relationship to the consumption of energy.

\footnotetext{
${ }^{1}$ Econometric command allows soften or remove trend.
} 
Faced with an increase in oil prices, this situation favors oil exploration in the country, it generates an important income for the country which translates into GDP growth, with a perverse effect, since increasing the price of oil, derived from it have the same trend and thus the consumer price index also increases, which motivates individuals to reduce their consumption in every way, a less clear with increase in relative prices.

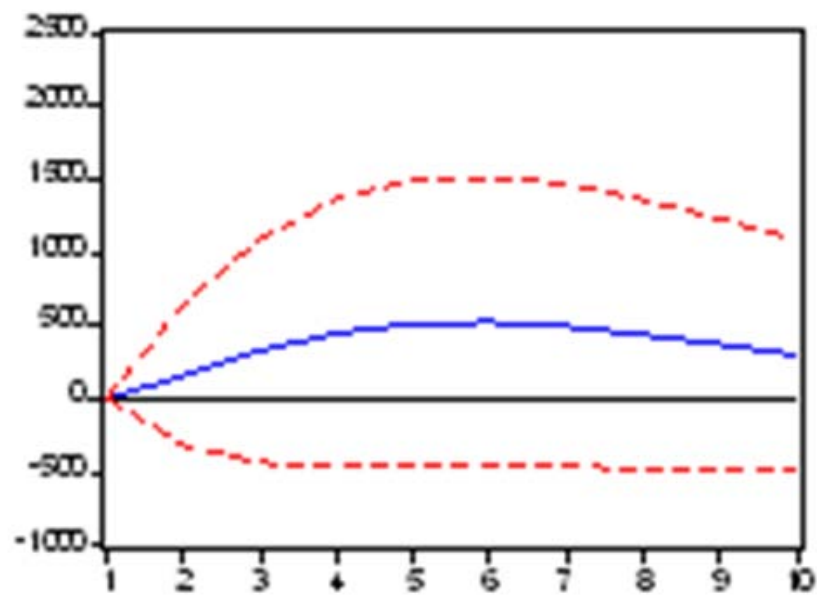

Figure 1. Energy consumption to shocks in GDP. Source: Authors’ calculations.

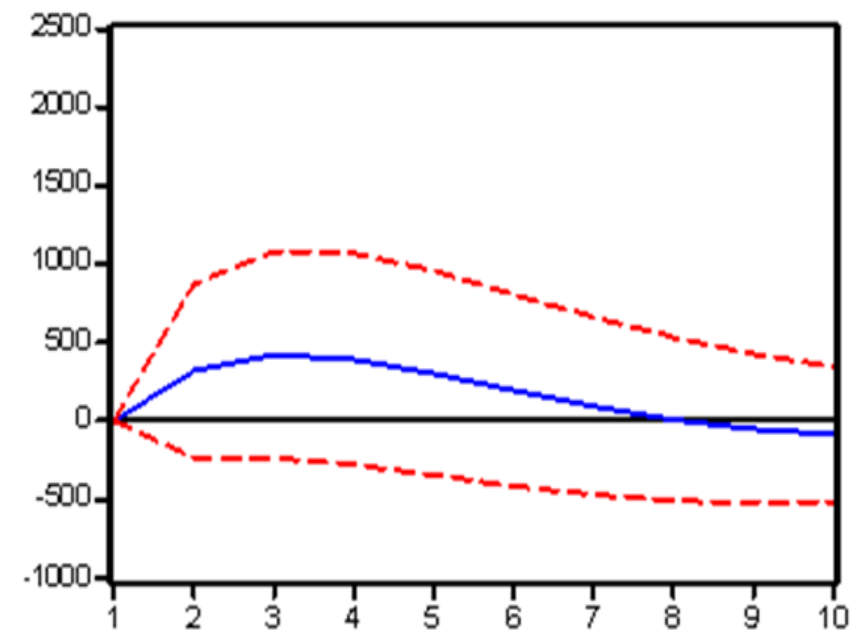

Figure 2. Energy consumption to shocks in the relative price of energy. Source: Authors' calculations.

Consumer Response Electrical (CEPE) versus shock in unemployment (U). Faced with a rising unemployment rate, energy consumption tends to decline in Ecuador, which provides a basis to justify the theory of Pindyck (1979) which stated that energy and employment are complementary. The responses to other variables are found in Appendix G.

\section{Variance Decomposition}

The power consumption measured thousands of barrels of oil is a factor that decreases in proportion to their average volatility. The relative prices of energy, are a non-volatile variable, its range is made from proporcional.de period 5 the variance tends to be constant. Unemployment has a tendency to grow in proportion to its variance, is not very volatile, and in fact rises. The GDP has a tendency to vary almost at an exponential rate, but despite that, the last two data are to normalize the variance. 


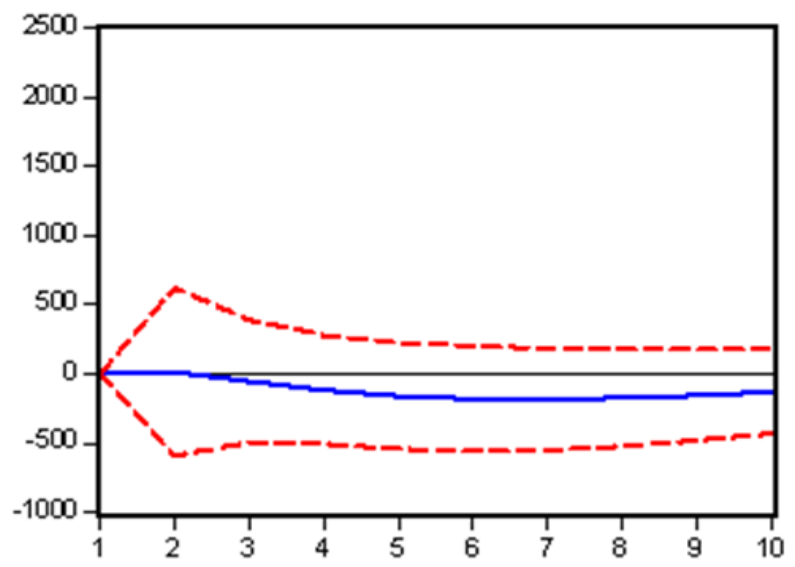

Figure 3. Energy consumption in front of unemployment shocks. Source: Authors' calculations.

\section{Conclusions}

From the results obtained in the model, the authors conclude that economic growth (GDP) and energy (CEPE) have a proportional relationship. This is because energy plays an important role in the production process of many sectors of economic activity in the country.

The long-term relative price tends to be inversely related to energy consumption, increasing these rates to condition power consumption in a perverse way.

As Pindyck (1979) stated that employment and consumption are complementary goods. And for the Ecuador data applied the theory, since the power consumption will decrease if unemployment increases.

This research outlines show the studies with respect to energy consumption and energy growth in Ecuador for the period 1973-2006, and the relationship of complementarity which is employment and energy, the second section presents the results of VAR model, using impulse response analysis and variance decomposition. Respective conclusions are made and finally presented in the Appendixes to the model tests.

The authors show that the relation between energy consumption and GDP is direct, positive relationship also in the GDP energy consumption with respect to that energy prices also show a positive trend in consumption showing no sustainability or at least weak sustainability.

\section{References}

Acosta, A. (2009). Curse of abundance (La Maldición de la Abundancia). Quito: Abya-Yala.

Caballero Güendolian, K., \& Galindo Paliza, L. M. (2006). Energyconsumption in Mexico and its effects on output and prices (El consumo de energía en México y sus efectos en el producto y los precios). Mexico: UNAM.

Central Bank of Ecuador. (BCE).(2010). Central bank of Ecuador. Retrieved 25 November, 2010, from http://www. bce.fin.ec

Chung, J. W. (1994). Utility and production function. Cambridge, M.A.: Blackwells.

Diaz, D. E. (2010). Energy and neoclassical growth theory. Journal of Economics and Statistics (SaberEs), 2.

Economic Commission for Latin America and the Caribbean (ComisiónEconómicaparaAmérica Latina y el Caribe, CEPAL). (2010). Publications statistics. Retrieved 25 November, 2010, from http://www.eclac.org/

Falconi Benitez, F. (1995). The politics of fuel price in Ecuador: 1972-1994 (La Poítica de los Precios de los Combustibles en el Ecuador: 1972-1994). Quito: FLACSO.

Falconi Benitez, F. (2002). Economy and sustainable development happy marriage or divorce announced? The case of Ecuador (Economía y Desarrollo Sostenible ¿Matrimonio felíz o divorcio anunciado?El caso de Ecuador). Quito: FLACSO.

Galindo, L. M., \& Sánchez, L. (2005). Energy consumption and the Mexican economy: An empirical analysis with VAR (El consumo de energía y la economía mexicana: un análisis empírico con VAR). Mexico: Network of Scientific Journals of Latin America and the Caribbean, Spain and Portugal. 
Howard, R. B., Schipper, L., \& Anderson, B. (1993). The structure and trends and intensity of energy use: Trends in five OECD nations. The Energy Journal, 14(2), 231-254.

Jorgenson, D. W. (1984). Econometric methods for applied general equilibrium analysis. In H. E. Scarf \& J. B. Shoven (Eds.), Applied General Equilibrium Analysis (pp. 139-203).

Jorgenson, D. W. (1998). Growth energy. The Environmental and Economics Growth, 2. MIT Press.

Mabey, N., Smith, C., Hall, S., \& Gupta, S. (1997). Argument in the greenhouse: The international economics of controlling global warming. Londres y New York, Routledge.

World Bank. (2010). World Bank data. Retrieved 25 November, 2010, from http://www.datos.bancomundial.org/

\section{Appendix A: Dickey-Fuller Augmented Test for Variable}

Test critical values:

Table A1

Dickey-Fuller Augmented Test of CEPE

\begin{tabular}{|l|l|l|l|}
\hline \multicolumn{2}{|l|}{ CEPE } & Statistic $t$ & Prob. \\
\hline \multirow{3}{*}{ Test critical values } & $1 \%$ & -0.120473 & 0.9397 \\
\hline & $5 \%$ & -3.621023 & \\
\hline
\end{tabular}

Note. Source: Authors' calculations based on econometric program Eviews 6 and Excel 2007. ECB and ECLAC data.

Table A2

Dickey-Fuller Augmented Test of GDP

\begin{tabular}{|l|l|l|l|l|}
\hline \multirow{2}{*}{ GDP } & Statistic $t$ & Prob. \\
\cline { 3 - 5 } \multicolumn{2}{l|}{ Test critical values } & $1 \%$ & 0.749831 & 0.9917 \\
\hline & $5 \%$ & -3626784 & \\
\hline & $10 \%$ & -2945842 & \\
\hline
\end{tabular}

Note. Source: Authors' calculations based on econometric program Eviews 6 and Excel 2007. ECB and ECLAC data.

Table A3

Dickey-Fuller Augmented Test of PPET

\begin{tabular}{|l|l|l|l|}
\hline \multicolumn{2}{|l|}{ PPET } & Statistic $t$ & Prob. \\
\cline { 2 - 4 } Test critical values & $1 \%$ & -1.018445 & 0.7355 \\
\hline & $5 \%$ & -3626784 & \\
\cline { 2 - 5 } & $10 \%$ & -2945842 & \\
\hline
\end{tabular}

Note. Source: Authors' calculations based on econometric program Eviews 6 and Excel 2007. ECB and ECLAC data.

Table A4

Dickey-Fuller Augmented Test of IPC

\begin{tabular}{|l|l|l|l|}
\hline \multirow{2}{*}{ IPC } & Statistic $t$ & Prob. \\
\hline \multirow{3}{*}{ Test critical values } & $1 \%$ & -0.785547 & 0.8083 \\
\hline & $5 \%$ & -3626784 & \\
\cline { 2 - 5 } & $10 \%$ & -2945842 & \\
\hline
\end{tabular}

Note. Source: Authors' calculations based on econometric program Eviews 6 and Excel 2007. ECB and ECLAC data.

Table A5

Dickey-Fuller Augmented Test of $U$

\begin{tabular}{|l|l|l|l|}
\hline \multirow{2}{*}{\begin{tabular}{l|l|} 
U \\
Test critical values
\end{tabular}} & Statistic $t$ & Prob. \\
\hline & $1 \%$ & -2.690470 & 0.0852 \\
\hline & $5 \%$ & -3626784 & \\
\cline { 2 - 5 } & $10 \%$ & -2945842 & \\
\hline
\end{tabular}

Note. Source: Authors' calculations based on econometric program Eviews 6 and Excel 2007. ECB and ECLAC data. 
These tables disclose that the series used for the VAR are no seasonality. If the probability of this test is greater than 0.05 , the series would be stationary. Otherwise will not.

Table B1

Appendix B: Autoregression Vector Estimation

Vector Autoregression Coefficients

Period: 1973-2006

\begin{tabular}{|l|c|c|c|c|}
\hline & CEPE & GDP & PPET/IPC & U \\
\hline CEPE(-1) & 0.613368 & -0.012546 & -0.007391 & 0.000398 \\
\hline GDP(-1) & $(0.18595)$ & $(0.04331)$ & $(0.00572)$ & $(0.00021)$ \\
\hline & 0.340819 & 0.786791 & 0.035516 & -0.001401 \\
\hline PPET(-1)/IPC(-1) & $(0.94768)$ & $(0.22074)$ & $(0.02915)$ & $(0.00106)$ \\
\hline & $5,524.985$ & 0.094864 & 0.626420 & 0.004565 \\
\hline U(-1) & -423.888 & $(0.98736)$ & $(0.13040)$ & $(0.00475)$ \\
\hline & $7,873.188$ & $-7,493.514$ & $-2,724.444$ & 0.191040 \\
\hline C & -187.152 & -435.930 & -575.716 & $(0.20971)$ \\
\hline & $3,072.914$ & $2,086.173$ & $3,236.829$ & $4,287.143$ \\
\hline @TREND & $(4,445.38)$ & $(1,035.46)$ & -136.749 & -498.110 \\
\hline & $3,622.071$ & $1,115.107$ & $-8,710.326$ & 0.285928 \\
\hline & -298.794 & -695.978 & -919.150 & $(0.33480)$ \\
\hline R-squared & {$[1.21223]$} & {$[1.60222]$} & {$[-0.94765]$} & {$[0.85402]$} \\
\hline
\end{tabular}

Note. Source: Authors’ calculations based on econometric program Eviews 6 and Excel 2007. ECB and ECLAC data.

Appendix C: VAR Model Specification

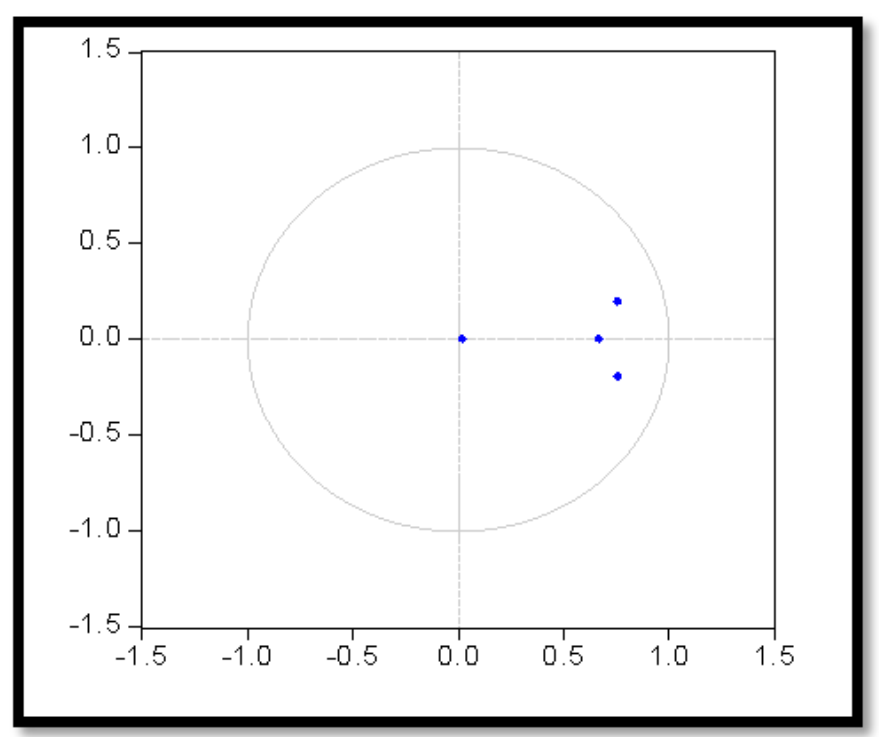

Figure C1. Source: Authors' calculations based on econometric program Eviews 6 and Excel 2007. ECB and ECLAC data.

The good specification of the model can see by the graphic unit root, while all the points are inside the circle, the estimated model is perfectly specified. In this case we use a trend variable (@ trend) when estimating the model, it is to normalize the laggards. 
Table D1

\section{Appendix D: Normality}

Coefficients of Normal

\begin{tabular}{|l|l|l|l|}
\hline Component & Jarque-Bera & $d f$ & Prob. \\
\hline 1 & 0.267441 & 2 & 0.8748 \\
\hline 2 & 2.236660 & 2 & 0.3268 \\
\hline 3 & 7.214464 & 2 & 0.0271 \\
\hline 4 & 2.525679 & 2 & 0.2828 \\
\hline Joint & $\mathbf{1 2 . 2 4 4 2 4}$ & $\mathbf{8}$ & $\mathbf{0 . 1 4 0 6}$ \\
\hline
\end{tabular}

Note. $\mathrm{H}_{0}$ : Normality; $\mathrm{H}_{1}$ : No normality. Source: Authors’ calculations based on econometric program Eviews 6 and Excel 2007. ECB and ECLAC data.

To accept the null hypothesis Jarque-Bera odds must be greater than 0.05 , otherwise it is rejected, it is safe. In this case, the model has a probability of normality 0.14 , the null hypothesis is accepted.

Table E1

Appendix E: Autocorrelation

Autocorrelation Tests

\begin{tabular}{|l|l|l|}
\hline Lags & LM-Stat & Probabilidad \\
\hline 1 & 9.467389 & 0.8929 \\
\hline 2 & 7.785602 & 0.9550 \\
\hline 3 & 11.34358 & 0.7878 \\
\hline 4 & 23.51613 & 0.1006 \\
\hline 5 & 13.01779 & 0.6715 \\
\hline 6 & 12.43349 & 0.7136 \\
\hline 7 & 12.38595 & 0.7170 \\
\hline 8 & 15.83944 & 0.4642 \\
\hline 9 & 15.32836 & 0.5007 \\
\hline 10 & 23.73871 & 0.0954 \\
\hline 11 & 8.972708 & 0.9145 \\
\hline 12 & 15.60972 & 0.4805 \\
\hline
\end{tabular}

Note. H0: No autocorrelation; H1: Autocorrelation. Source: Authors' calculations based on econometric program Eviews 6 and Excel 2007. ECB and ECLAC data.

For the VAR model passes the test of autocorrelation lags, the probability must be greater than 0.05 , as normal as it is safe. So this model has no autocorrelation, as all odds are better than 0.05 .

\section{Appendix F: Heteroscedasticity}

Table F1

Heteroscedasticity Tests

\begin{tabular}{|l|l|l|}
\hline \multicolumn{2}{|l|}{ Test en conjunto: } & \\
\hline Chi-sq & $d f$ & Probabilidad. \\
\hline 88.52237 & 100 & 0.7874 \\
\hline
\end{tabular}

Note. H0: homoskedasticity; H1: Heteroscedasticity. Source: Authors' calculations based on econometric program Eviews 6 and Excel 2007. ECB and ECLAC data.

As in previous tests accept the null hypothesis, the probability of the test must be greater than 0.05 , in this case meets the condition, which means that the model is homoskedastic VAR. 
Appendix G: Impulse Response

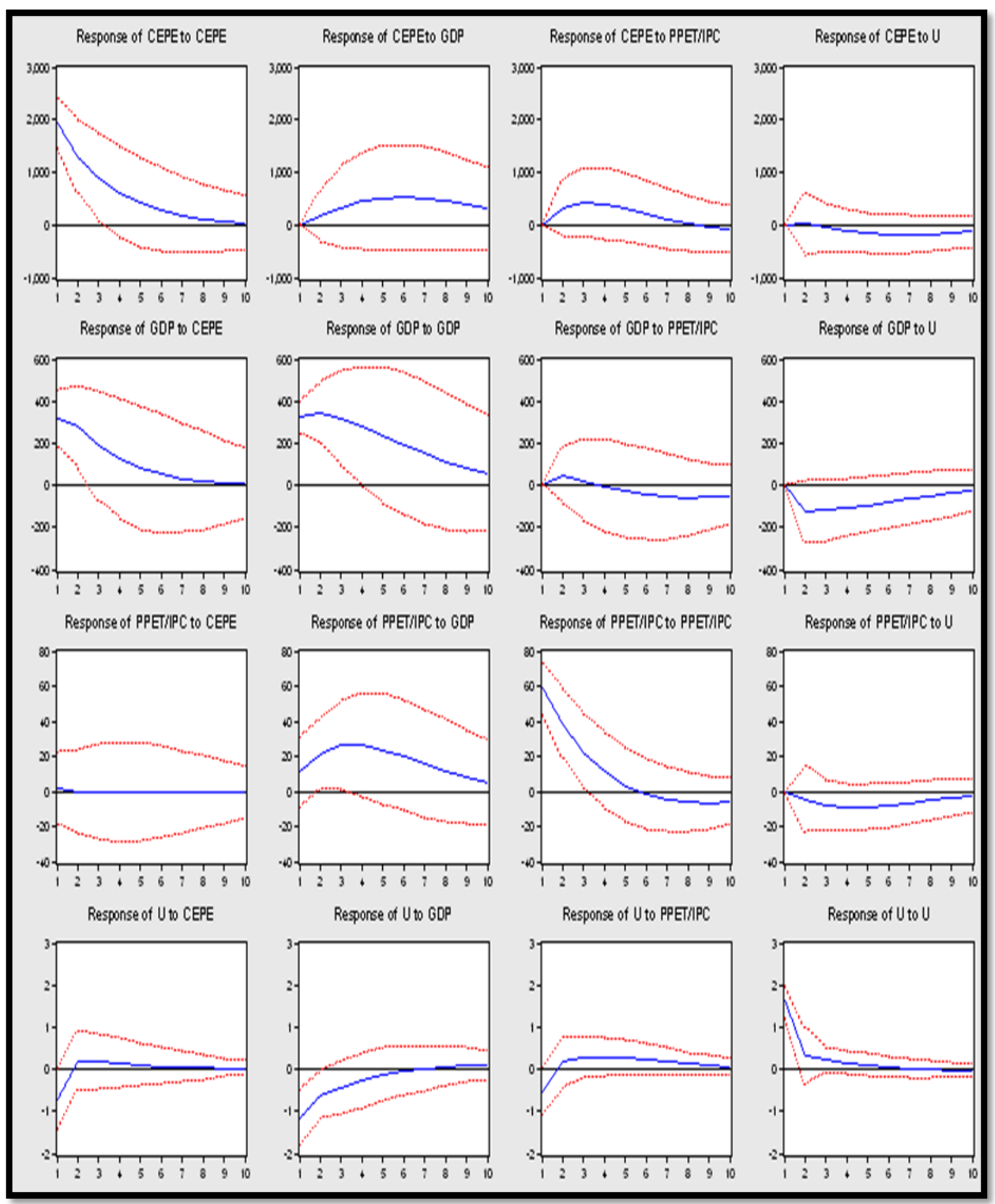

Figure G1. Source: Authors' calculations based on econometric program Eviews 6 and Excel 2007. ECB and ECLAC data. 
Appendix H: Variance Decomposition (CEPE)

Table H1

The Volatility of the Variables

\begin{tabular}{llllll}
\hline Period & S.E. & CEPE & GDP & PPET/IPC & U \\
\hline 1 & $1,933.221$ & 100.0000 & 0.000000 & 0.000000 & 0.000000 \\
2 & $2,354.420$ & 97.69761 & 0.466325 & 1.833147 & 0.002918 \\
3 & $2,573.332$ & 93.70916 & 2.012108 & 4.230049 & 0.048683 \\
4 & $2,712.989$ & 89.31608 & 4.538633 & 5.915696 & 0.229595 \\
5 & $2,812.356$ & 85.25276 & 7.539484 & 6.670968 & 0.536788 \\
6 & $2,886.375$ & 81.84358 & 10.45935 & 6.790501 & 0.906572 \\
7 & $2,941.682$ & 79.17251 & 12.91907 & 6.638960 & 1.269460 \\
8 & $2,982.047$ & 77.19529 & 14.76504 & 6.461900 & 1.577775 \\
9 & $3,010.382$ & 75.80678 & 16.01594 & 6.365921 & 1.811350 \\
10 & $3,029.342$ & 74.88133 & 16.78326 & 6.364118 & 1.971297 \\
\hline
\end{tabular}

Note. Source: Authors' calculations based on econometric program Eviews 6 and Excel 2007. ECB and ECLAC data. 